\title{
Article
}

\section{Antifungal and Anti-Inflammatory Potential of Bupleurum rigidum subsp. paniculatum (Brot.) H.Wolff Essential Oil}

\author{
Mónica Zuzarte ${ }^{1,2,3, *}$, Pedro M. P. Correia ${ }^{4} \mathbb{D}^{\text {, Jorge M. Alves-Silva }}{ }^{1,2,3,5} \mathbb{C}^{\text {, Maria J. Gonçalves }}{ }^{5,6}$,

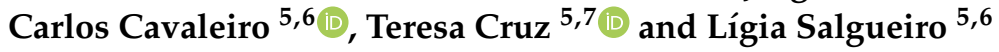 \\ 1 Faculty of Medicine, Coimbra Institute for Clinical and Biomedical Research (iCBR), University of Coimbra, \\ 3000-548 Coimbra, Portugal; jmasilva@student.ff.uc.pt \\ 2 Center for Innovative Biomedicine and Biotechnology (CIBB), University of Coimbra, \\ 3000-548 Coimbra, Portugal \\ 3 Clinical Academic Centre of Coimbra (CACC), 3000-548 Coimbra, Portugal \\ 4 Faculty of Sciences, BioISI-Biosystems \& Integrative Sciences Institute, University of Lisboa, \\ 1749-016 Lisboa, Portugal; pmpcorreia@fc.ul.pt \\ 5 Faculty of Pharmacy, University of Coimbra, 3000-548 Coimbra, Portugal; mpinho@ff.uc.pt (M.J.G.); \\ cavaleir@ff.uc.pt (C.C.); trosete@ff.uc.pt (T.C.); ligia@ff.uc.pt (L.S.) \\ 6 Chemical Process Engineering and Forest Products Research Centre (CIEPQPF), Department of Chemical \\ Engineering, University of Coimbra, 3030-790 Coimbra, Portugal \\ 7 Centre for Neuroscience and Cell Biology (CNC), 3000-548 Coimbra, Portugal \\ * Correspondence: mzuzarte@uc.pt
}

check for

updates

Citation: Zuzarte, M.; Correia, P.M.P.; Alves-Silva, J.M.; Gonçalves, M.J.; Cavaleiro, C.; Cruz, T.; Salgueiro, L. Antifungal and Anti-Inflammatory Potential of Bupleurum rigidum subsp. paniculatum (Brot.) H.Wolff Essential Oil. Antibiotics 2021, 10, 592. https:// doi.org/10.3390/antibiotics10050592

Academic Editors: Carla Sabia and Ramona Iseppi

Received: 2 April 2021

Accepted: 7 May 2021

Published: 17 May 2021

Publisher's Note: MDPI stays neutral with regard to jurisdictional claims in published maps and institutional affiliations.

Copyright: (c) 2021 by the authors. Licensee MDPI, Basel, Switzerland. This article is an open access article distributed under the terms and conditions of the Creative Commons Attribution (CC BY) license (https:/ / creativecommons.org/licenses/by/ $4.0 /)$.

\begin{abstract}
Fungal infections remain a major health concern with aromatic plants and their metabolites standing out as promising antifungal agents. The present study aims to assess, for the first time, the antifungal and anti-inflammatory potential of Bupleurum subsp. paniculatum (Brot.) H.Wolff essential oil from Portugal. The oil obtained by hydrodistillation and characterized by GC-MS, showed high amounts of monoterpene hydrocarbons, namely $\alpha$-pinene (29.0-36.0\%), $\beta$-pinene (26.1-30.7\%) and limonene (10.5-13.5\%). The antifungal potential was assessed, according to CLSI guidelines, against several clinical and collection strains. The essential oil showed a broad fungicidal effect being more potent against Cryptococcus neoformans and dermatophytes. Moreover, a significant germ tube inhibition was observed in Candida albicans as well as a disruption of mature biofilms, thus pointing out an effect of the oil against relevant virulent factors. Furthermore, fungal ultrastructural modifications were detected through transmission electron microscopy, highlighting the nefarious effect of the oil. Of relevance, the oil also evidenced anti-inflammatory activity through nitric oxide inhibition in macrophages activated with lipopolysaccharide. In addition, the essential oil's bioactive concentrations did not present toxicity towards macrophages. Overall, the present study confirmed the bioactive potential of B. rigidum subsp. paniculatum essential oil, thus paving the way for the development of effective drugs presenting concomitantly antifungal and anti-inflammatory properties.
\end{abstract}

Keywords: antifungal; germ tube; biofilm; anti-inflammatory

\section{Introduction}

Fungal infections account for nearly 1.6 million deaths worldwide, thus presenting a huge socio-economic burden, frequently neglected by public health authorities [1]. Most fungal infections affect mucous membranes, especially vaginal and mouth membranes [2] and, despite being primarily superficial, mycosis can rapidly evolve into systemic infections, especially in immunocompromised individuals. These type of infections are mainly caused by Candida albicans, nevertheless other Candida species are becoming important etiological agents such as C. krusei, C. parapsilosis and C. tropicalis [3]. Several features contribute to Candida spp. virulence including yeast-to-hypha morphological transition and biofilm formation [4]. The first, starts with germ tube formation that develop into hypha promoting 
tissue penetration and immune avoidance, thus resulting in a more effective infection. In addition, this transition is necessary for biofilm formation [5]. These complex structures can be formed in both biological and artificial surfaces and constitute a major clinical burden due to their higher resistance to antifungal drugs [6]. In fact, for most conventional antifungals, the minimal inhibitory concentration necessary to inhibit biofilms is 100 -fold higher than the concentrations needed to inhibit planktonic cells [7]. Fungal infections can also be caused by other yeast such as Cryptococcus neoformans which affects the central nervous system and by dermatophytes of the Trichophyton, Microsporum and Epidermophyton genera. Dermatophytes are able to colonize keratinized structures, such as hair, skin and nails. Furthermore, filamentous fungi from the Aspergillus genus, especially A. fumigatus, A. flavus and $A$. niger, are also important agents in the development of bloodstream systemic infections as well as pulmonary and allergic infections [8].

Current antifungal therapy continues to present several limitations due to safety issues, pharmacokinetics, narrow activity spectrum and low number of targets [9] For example, polyenes and amphotericin B are highly toxic whereas azoles, like fluconazole, only present a fungistatic effect. In addition, the emergence of resistant strains also compromises the effectiveness of these antifungals $[10,11]$.

Importantly, fungal infections also trigger an inflammatory response when fungal epitopes such as zymosan, bind to toll-like receptors (TLRs) in the host cells. TLRs binding triggers a series of intracellular cascades that culminate with the activation of pro-inflammatory transcription factors as well as the expression of several inflammatory cytokines such as interleukin-1 $\beta$ (IL-1 $\beta$ ), IL-6 and TNF- $\alpha$, which further fuel the inflammatory response [12,13]. In addition, TLRs binding also leads to the production of reactive oxygen and nitrogen species, such as nitric oxide [14] due to an increase in the production of key pro-inflammatory enzymes, such as inducible nitric oxide synthase (iNOS) and cyclooxygenase-2 (COX-2) [15].

In some disorders such as gastrointestinal tract inflammatory diseases, like Chron's disease, the colonization by Candida spp. is promoted leading to an exacerbated production of inflammatory cytokines which further worsens the inflammatory condition [16]. This triggers an endless circle of infection-inflammation that is generally controlled by the use of anti-inflammatory drugs. Nevertheless, these drugs have several side effects, including gastrointestinal, cardiovascular, hepatic, renal, cerebral and pulmonary complications [17]. Therefore, the development of new antifungal and anti-inflammatory agents with less side effects is mandatory and compounds showing concomitantly both properties represent a valuable therapeutic strategy.

In this context, aromatic and medicinal plants, especially those belonging to the Lamiaceae and Apiaceae families, emerge as promising sources of antifungal and/or anti-inflammatory agents. Indeed, species from the Apiaceae family have been used for centuries in traditional medicine for the treatment of several pathologies. Their beneficial effects are often related to the presence of essential oils, with reported antifungal and anti-inflammatory properties $[18,19]$. However, many uses are based on empiric knowledge, and the spectrum of action as well as the underlying mechanisms of action remain unknown, thus justifying scientific-based studies to further contribute to the development of effective therapeutics.

Bupleurum L. is one of the largest genus of the Apiaceae (Umbelliferae) family. Species from this genus are used in Asia, North Africa and Europe for their medicinal properties and have been used for millennia in traditional Chinese medicine [20]. For example, in Spain these species are used for the treatment of topical inflammation, as anti-infective and to promote wound healing [21], thus suggesting an antimicrobial and anti-inflammatory potential. Several secondary metabolites have also been described in Bupleurum species, including saikosaponins, flavonoids and volatile oils [20]. Moreover, different studies have also shown their anti-inflammatory [22-24]; hepatoprotection [25,26], antioxidant $[22,27,28]$, antifungal and antibacterial potential $[29,30]$. In addition, a patent for the use of B. fruticosum essential oil as an anti-ageing agent has been filled by L'Oréal [31], thus reinforcing the industrial and pharmaceutical interest of this genus. 
Among Bupleurum species, B. rigidum L. is one of the most widely represented in Portugal. This species is widely used in Spain for the treatment of topical inflammation, as anti-diarrheic and against furuncles [21]. Two subspecies of B. rigidum have been described, namely subsp. paniculatum and subsp. rigidum. B. rigidum subsp. paniculatum (Brot.) H.Wolff is an endemic species to the south and center of Portugal, Andalucía (Spain) and North Africa [32] and, up to date, no studies on this subspecies have been conducted. Therefore, and as part of our ongoing studies on the valorization of wild Apiaceae species, we aim to characterize the essential oil composition of B. rigidum subsp. paniculatum from Portugal and assess its bioactive potential. A combined antifungal and anti-inflammatory potential for B. rigidum subsp. paniculatum essential oil is reported, with emphasis on its effect against $C$. albicans virulence factors.

\section{Results}

\subsection{Essential Oil Composition}

Table 1 summarizes the chemical profile of two samples of B. rigidum subsp. paniculatum analyzed by GC-MS. A yield of $0.7 \%(w / v)$ was obtained for the essential oil from Coimbra and $0.6 \%$ for the oil from Fátima. More than 95\% of the compounds were identified in both samples.

Table 1. Chemical composition of Portuguese Bupleurum rigidum subsp. paniculatum essential oil.

\begin{tabular}{|c|c|c|c|c|}
\hline Compound * & $\begin{array}{c}\text { RI } \\
\text { SPB-1 }^{a}\end{array}$ & $\underset{S W 10^{b}}{\text { RI }}$ & $\begin{array}{c}\text { Coimbra } \\
(\%)\end{array}$ & $\begin{array}{c}\text { Fátima } \\
(\%)\end{array}$ \\
\hline$\alpha$-Thujene & 922 & 1029 & 0.3 & 0.1 \\
\hline$\alpha$-Pinene & 930 & 1030 & 36.0 & 29.0 \\
\hline Camphene & 943 & 1077 & 0.2 & 0.4 \\
\hline Fenchene & 943 & 1067 & 0.1 & 0.1 \\
\hline Sabinene & 964 & 1128 & 2.0 & 2.6 \\
\hline$\beta$-Pinene & 970 & 1118 & 26.1 & 30.7 \\
\hline Myrcene & 981 & 1160 & 1.8 & 10.0 \\
\hline$\alpha$-Phellandrene & 997 & 1171 & 0.3 & 0.1 \\
\hline$\alpha$-Terpinene & 1006 & 1183 & $\mathrm{t}$ & $\mathrm{t}$ \\
\hline p-Cymene & 1009 & 1271 & 0.2 & $\mathrm{t}$ \\
\hline Limonene & 1021 & 1204 & 10.5 & 13.5 \\
\hline$\beta$-Phellandrene & 1021 & 1214 & 9.4 & 4.5 \\
\hline Z- $\beta$-Ocimene & 1025 & 1235 & 4.1 & 1.0 \\
\hline$E$ - $\beta$-Ocimene & 1035 & 1253 & 5.1 & 2.0 \\
\hline$\gamma$-Terpinene & 1046 & 1249 & 0.3 & 0.2 \\
\hline Terpinolene & 1076 & 1288 & 0.1 & 0.1 \\
\hline Monoterpene hydrocarbons & & & 96.6 & 94.4 \\
\hline Linalool & 1082 & 1543 & $\mathrm{t}$ & $\mathrm{t}$ \\
\hline$\alpha$-Pinene-xide & 1077 & 1370 & $\mathrm{t}$ & $\mathrm{t}$ \\
\hline allo-Ocimene & 1118 & 1370 & 0.1 & 0.1 \\
\hline Terpinene-4-ol & 1159 & 1595 & 0.1 & $\mathrm{t}$ \\
\hline Myrtenal & 1176 & 1786 & 0.1 & $\mathrm{t}$ \\
\hline$\alpha$-Terpineol & 1168 & 1692 & $\mathrm{t}$ & $\mathrm{t}$ \\
\hline Bornyl acetate & 1266 & 1578 & 0.1 & 0.1 \\
\hline Oxygen containing monoterpenes & & & 0.5 & 0.3 \\
\hline$\alpha$-Copaene & 1364 & 1487 & 0.1 & $\mathrm{t}$ \\
\hline$\beta$-Cubebene & 1380 & 1538 & $\mathrm{t}$ & $\mathrm{t}$ \\
\hline E-Caryophyllene & 1408 & 1590 & 0.2 & 0.1 \\
\hline$\gamma$-Elemene & 1417 & 2136 & $\mathrm{t}$ & $\mathrm{t}$ \\
\hline$\alpha$-Humulene & 1442 & 1665 & $\mathrm{t}$ & $\mathrm{t}$ \\
\hline Germacrene-D & 1466 & 1699 & 1.7 & 0.5 \\
\hline Bicyclogermacrene & 1478 & 1727 & 0.2 & 0.1 \\
\hline$\delta$-Cadinene & 1508 & 1751 & 0,1 & $\mathrm{t}$ \\
\hline Sesquiterpene hydrocarbons & & & 2.4 & 0.8 \\
\hline Spathulenol & 1551 & 2112 & $\mathrm{t}$ & $\mathrm{t}$ \\
\hline Caryophyllene oxide & 1557 & 1968 & $\mathrm{t}$ & $\mathrm{t}$ \\
\hline Oxygen containing sesquiterpenes & & & 0.1 & 0.1 \\
\hline Total identified & & & 99.6 & 95.6 \\
\hline
\end{tabular}

* Compounds listed in order of elution in the SPB-1 column; $t<0.05 \%$. ${ }^{\text {a }}$ RI SPB 1: GC retention indices relative to C9-C23 n-alkanes on the SPB-1 column. ${ }^{b}$ RI SW 10: GC retention indices relative to C9-C23 n-alkanes on the Supelcowax-10 column. 
The chemical analysis showed that both essential oils are characterized by the presence of high amounts of monoterpene hydrocarbons (94.4-96.6\%), mainly $\alpha$-pinene (29.0-36.0\%), $\beta$-pinene (26.1-30.7\%) and limonene (10.5-13.5\%). The essential oil from Coimbra region represents a much larger population and, therefore, was selected to assess the antifungal and anti-inflammatory potential of the oil.

\subsection{Antifungal Activity}

2.2.1. The Essential Oil Showed a Broad-Spectrum Fungicidal Effect

The antifungal potential of $B$. rigidum subsp. paniculatum essential oil was assessed against several yeast, dermatophyte and Aspergillus strains as depicted in Table 2. Besides collection strains, fungal isolates obtained from the clinic were also assessed, thus providing data on the antifungal potential of the oil against more resistant strains. Overall, the essential oil showed a significant antifungal effect against Cryptococcus neoformans and Trichophytum rubrum with MIC values of $72 \mu \mathrm{g} / \mathrm{mL}$ (Table 2). For the remaining dermatophytes, the oil was also effective with MIC values ranging from $144 \mu \mathrm{g} / \mathrm{mL}$ to $288 \mu \mathrm{g} / \mathrm{mL}$. In addition, relevant antifungal effects were observed for Aspergillus and the majority of Candida strains (Table 2). Interestingly for the majority of the tested stains, the oil showed similar MIC and MLC values, thus presenting a fungicidal effect (Table 2). This is quite relevant since azoles, namely flucanozole, an antifungal drug widely used in the clinic, shows primarily fungistatic effects. Indeed, this antifungal drug, for the majority of the tested strains, is able to inhibit fungal growth but at the MIC it is not lethal to the fungi.

Table 2. Antifungal activity of Bupleurum rigidum subsp. paniculatum essential oil.

\begin{tabular}{|c|c|c|c|c|}
\hline \multirow{2}{*}{ Strains } & \multicolumn{2}{|c|}{ Essential Oil } & \multicolumn{2}{|c|}{ Fluconazole } \\
\hline & MIC & MLC & MIC & MLC \\
\hline Candida albicans ATCC 10231 & 576 & 576 & 1 & $>128$ \\
\hline Candida tropicalis ATCC 13803 & 1125 & 1125 & 4 & $>128$ \\
\hline Candida krusei H9 & 288 & 288 & 64 & $64-128$ \\
\hline Candida guillermondii MAT23 & 288 & 288 & 8 & 8 \\
\hline Candida parapsilosis ATCC 90018 & 576 & 576 & 1 & $1-2$ \\
\hline Cryptococcus neoformans CECT 1078 & 72 & 144 & 16 & 128 \\
\hline Trichophytum mentagrophytes FF7 & 288 & 288 & $16-32$ & $32-64$ \\
\hline Trichophytum mentagrophytes var. interdigitale CECT 2958 & 288 & 288 & 128 & $\geq 128$ \\
\hline Trichophyton rubrum CECT 2794 & 72 & 72 & 16 & 64 \\
\hline Trichophytum verrucosum CECT 2992 & 288 & 288 & 128 & $>128$ \\
\hline Microsporum canis FF1 & 144 & 144 & 128 & 128 \\
\hline Microsporum gypseum CECT 2905 & 288 & 288 & 128 & $>128$ \\
\hline Epidermophyton floccosum FF9 & 144 & 144 & 16 & 16 \\
\hline Aspergillus niger ATCC 16404 & 288 & 1125 & n.t & n.t \\
\hline Aspergillus fumigatus ATCC 46645 & 576 & 576 & n.t & n.t \\
\hline Aspergillus flavus F44 & 576 & 576 & n.t & n.t \\
\hline
\end{tabular}

MIC-minimal inhibitory concentration and MLC-minimal lethal concentration determined by a macrodilution method and expressed as $\mu \mathrm{g} / \mathrm{mL}$; n.t-not tested.

\subsubsection{The Essential Oil was Effective against Candida albicans Virulent Factors}

Candida albicans is able to switch from yeast-to-hypha morphology promoting tissue invasiveness [33] and to form biofilms, an organized structure more resistant to antifungal agents than planktonic fungi [34]. These features play a pivotal role in C. albicans pathogenesis and virulence, thus constituting promising therapeutic targets. Therefore, the present study aimed to assess the effect of the essential oil on both features (Figures 1 and 2). As shown in Figure 1, the essential oil strongly inhibited germ tube formation in C. albicans at concentrations well below its respective MIC. Interestingly, at concentrations as low 
as MIC $/ 8(72 \mu \mathrm{g} / \mathrm{mL})$ the oil inhibited germ tube formation by ca. $40 \%$ and at MIC $/ 4$ $(144 \mu \mathrm{g} / \mathrm{mL}), 88 \%$ of inhibition was observed (Figure 1a). Fluconazole failed to accomplish this up to $200 \mu \mathrm{g} / \mathrm{mL}$, as pointed out in Figure 1b, thus highlighting the relevance of our results.

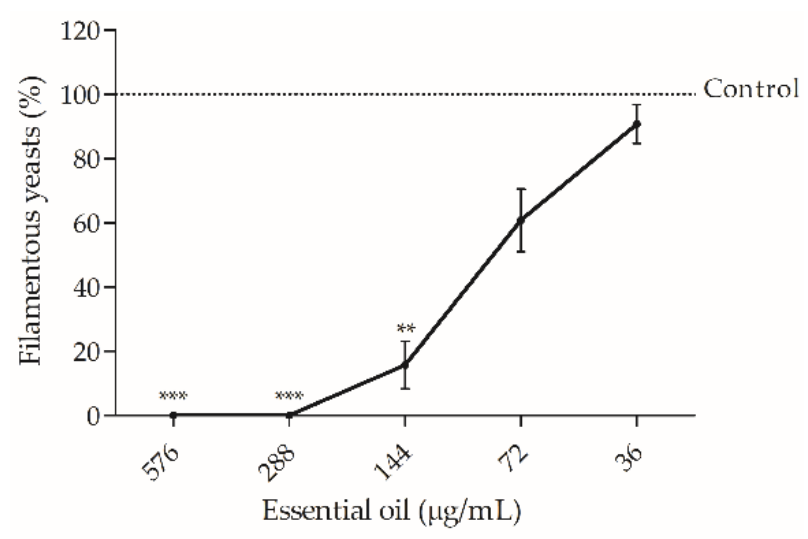

(a)

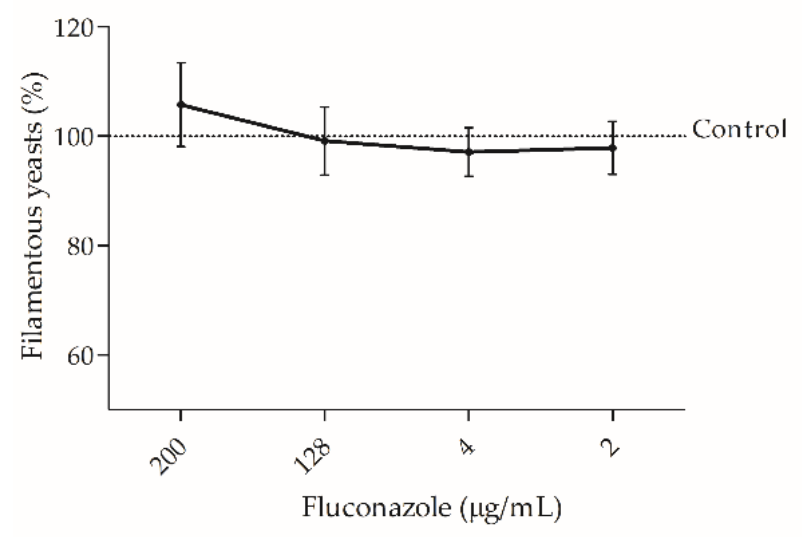

(b)

Figure 1. Filamentation percentage of Candida albicans ATCC 10231 treated with different concentrations of Bupleurum rigidum subp. paniculatum essential oil (a) or treated with fluconazole (b). One-way ANOVA followed by Dunnett's Multiple Comparison Test, ${ }^{* *} p<0.01$; ${ }^{* * *} p<0.001$, compared to control.

The capacity of the essential oil to decrease biofilm mass and biofilm viabilitywas also tested as well as that of fluconazole (Figure 2). Overall, the oil was effective and decreased biofilm viability at concentrations similar to the respective MIC and at a slightly higher concentration, the oil also disrupted mature biofilms (Figure 2a). Fluconazole, on the other hand, was only effective in decreasing $C$. albicans viability at a much higher concentration than its respective MIC and was ineffective in reducing biofilm mass even at concentration $200 \times$ higher than its MIC, as shown in Figure $2 b$.

\subsubsection{The Essential Oil Modified the Ultrastructure of Candida albicans and} Trichophyton rubrum

Bearing in mind the promising fungicidal effect observed against T. rubrum as well as the inhibition of virulence factors registered in C. albicans, both strains were selected to further elucidate the effect of the essential oil at an ultrastructural level. For this, transmission electron microscopy analysis were performed. Figures 3 and 4 compile representative images of the alterations observed in C. albicans and T. rubrum, respectively, in comparison to non-treated fungal cells. Overall, untreated cells showed a well-defined surface with and 
integral cell wall (Figure 3a,b; Figure 4a,b) while treated cells (Figure 3c-h; Figure 4c-h) presented a structural disorganization, particularly at the cell wall (e.g., Figures $3 \mathrm{c}$ and $4 \mathrm{c}$ ), for $C$. albicans and T. rubrum respectively. These alterations can be due to an impairment in the deposition of cell wall constituents. In C. albicans cytoplasmic disintegration was also observed (e.g., Figure 3h). Particularly for T. rubrum an increased number of vacuoles was observed with the accumulation of electron dense material (Figure $4 \mathrm{c}-\mathrm{h}$ ), reflecting a defensive mechanism of the fungus. As the number of vacuoles significantly increased with the essential oil treatment, it seems that autophagy is activated [35]. Indeed, autophagic structures were observed (Figure $4 \mathrm{~h}$ ), thus suggesting that the oil activates this pathway as a protective mechanism of the fungi.

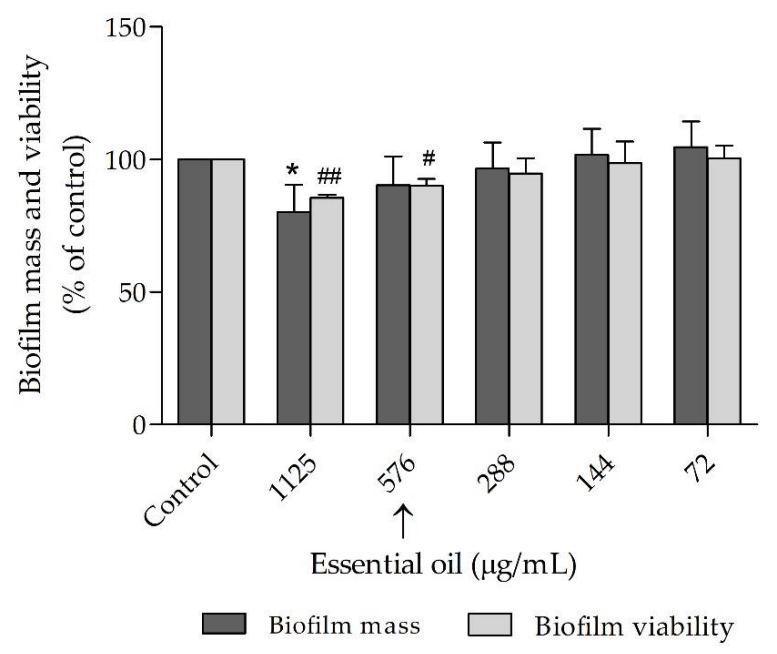

(a)

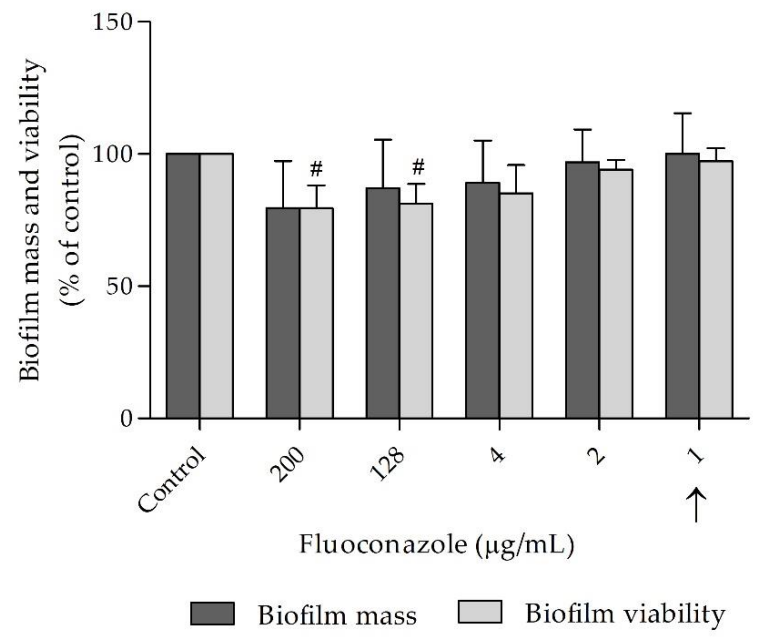

(b)

Figure 2. Effect of Bupleurum rigidum subp. paniculatum essential oil (a) and fluoconazole (b) on Candida albicans ATCC 10231 biofilm biomass and viability. One-way ANOVA followed by Dunnett's multiple comparison test (performed in separate on each feature), ${ }^{*} p<0.05$, compared to biofilm mass control; $\# p<0.05$ and \#\# $p<0.01$, compared to biofilm viability control; arrows indicate MIC value.

\subsection{Anti-Inflammatory Activity}

Chronic inflammation contributes to the successful colonization of the host tissues by pathogenic fungi, thus compromising disease suppression. Indeed, an antifungal drug with inherent anti-inflammatory activity, would enable a rapid symptomatic relief while providing an effective treatment. Therefore, we also assessed the anti-inflammatory 
potential of the essential oil using an in vitro model of lipopolysaccharide (LPS)-stimulated macrophages. The effect on NO production, a canonical marker of inflammation, was analyzed by measuring the accumulation of nitrites in the culture medium. Moreover, the effect of the oil on macrophages' viability was also tested (Figure 5). Expectably, our results show that macrophages without LPS stimuli produced residual levels of nitrites $(<1 \mu \mathrm{M})$ and this value increased to $35.25 \pm 3.91 \mu \mathrm{M}$ in the presence of LPS (Figure 5a). Interestingly, nitrite production was significantly reduced in the presence of the essential oil, attaining a decrease of more than $51 \%$ with $576 \mu \mathrm{g} / \mathrm{mL}$ of the oil $(17.15 \pm 3.35 \mu \mathrm{M})$ and a decrease of $33 \%$ with half the concentration ( $23.53 \pm 3.93 \mu \mathrm{M}$; Figure $5 \mathrm{a})$. Importantly, all the tested concentrations of the essential oil did not affect macrophages' viability (Figure 5b), thus confirming a safety profile of the oil at concentrations exhibiting pharmacological activity.

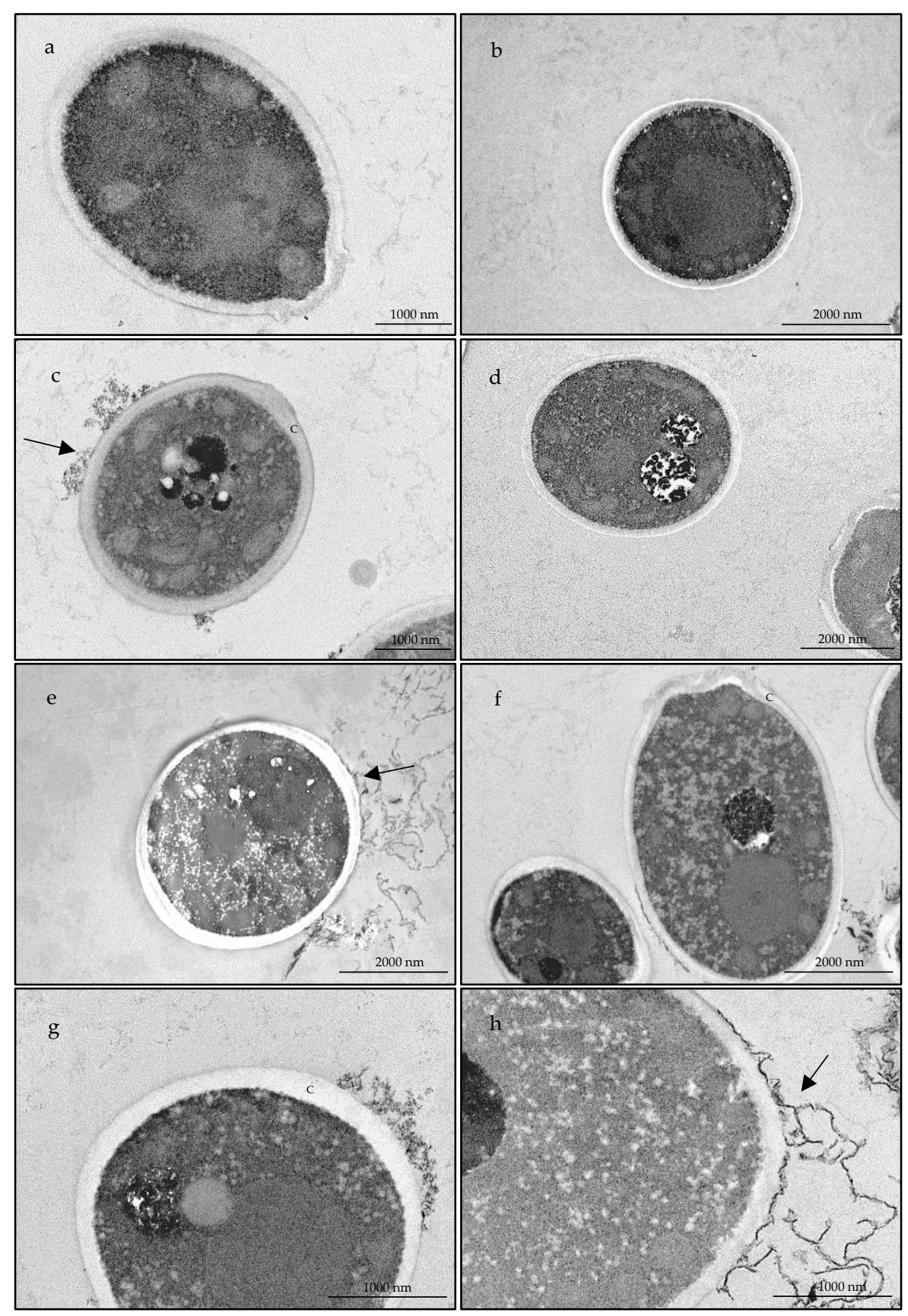

Figure 3. Transmission electron microscopic observations of Candida albicans in the presence of DMSO $(\mathbf{a}, \mathbf{b})$ or treated with of $72 \mu \mathrm{g} / \mathrm{mL}$ of Bupleurum rigidum subsp. paniculatum essential oil (c-h). Arrow points to fragments from the cell wall; c-cell wall. 


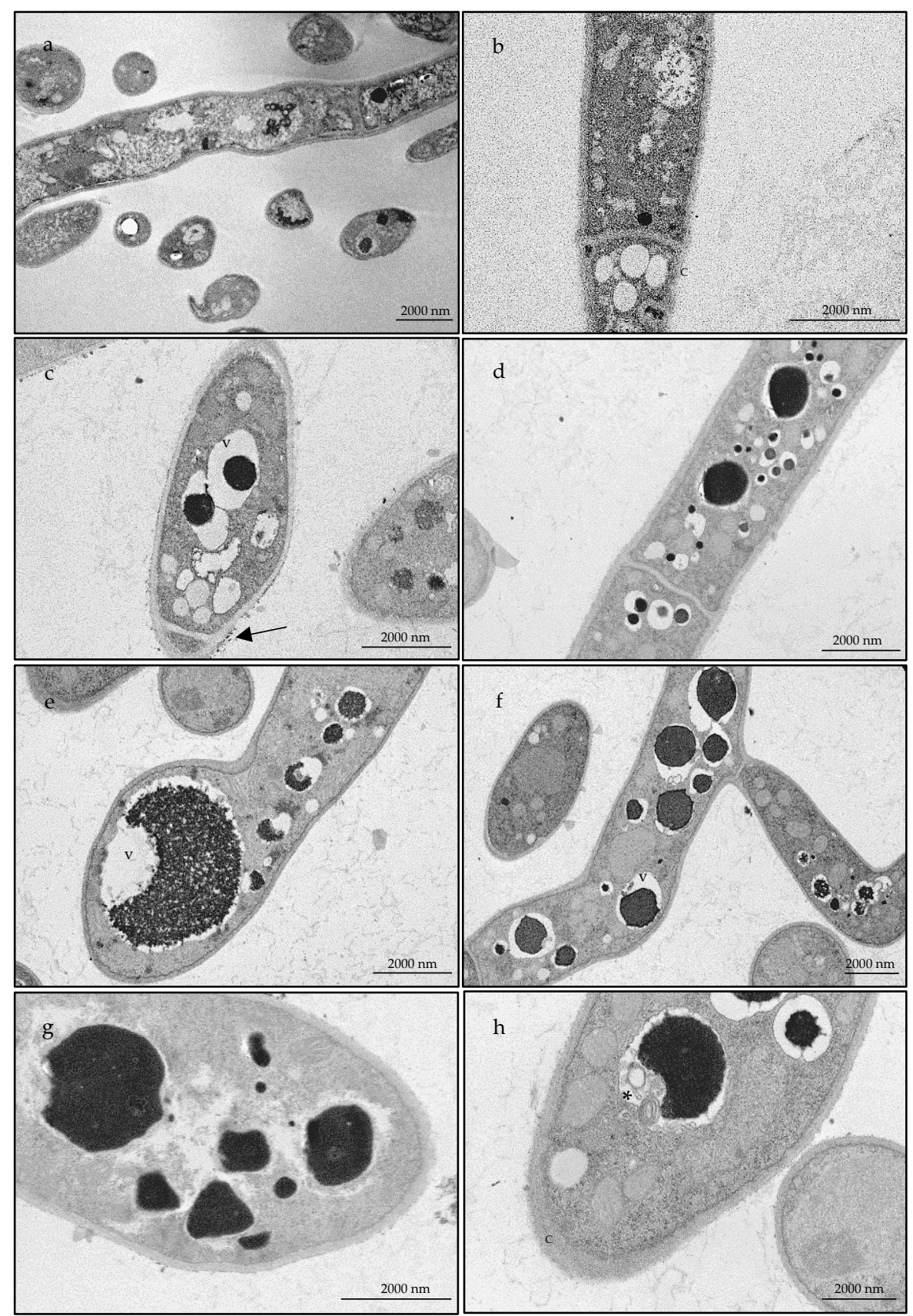

Figure 4. Transmission electron microscopic observations of Trichophyton rubrum in the presence of DMSO $(\mathbf{a}, \mathbf{b})$ or treated with of $576 \mu \mathrm{g} / \mathrm{mL}$ of Bupleurum rigidum subsp. paniculatum essential oil (c-h). Arrow points to fragments from the cell wall; * shows an autophagic structure; c-cell wall, $\mathrm{v}$-vacuoles. 


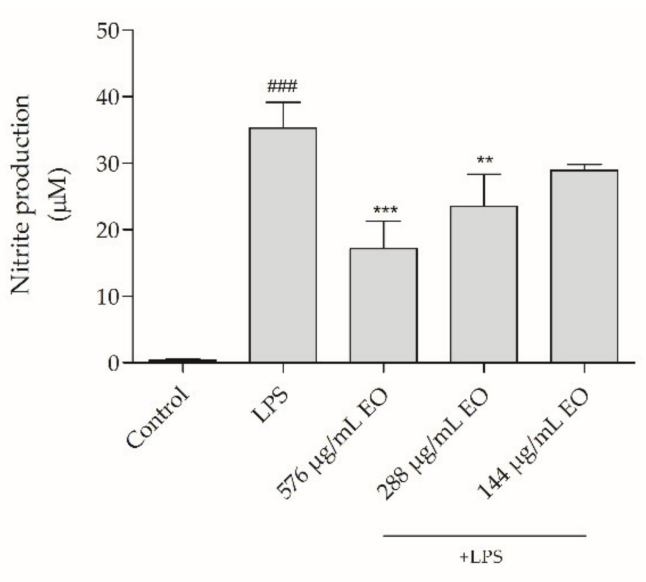

(a)

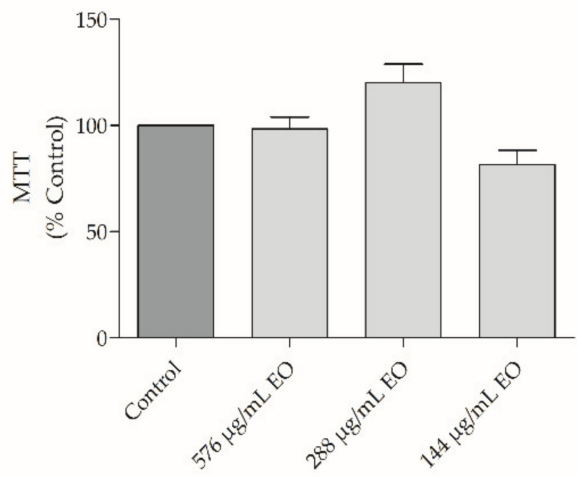

(b)

Figure 5. Effect of Bupleurum rigidum subp. paniculatum essential oil on NO production (a) and cell viability (b). One-way ANOVA followed by Dunnett's Multiple Comparison Test, \#\#\# $p<0.001$, compared to control; ${ }^{* *} p<0.01{ }^{* * *} p<0.001$, compared to LPS. EO-essential oil.

\section{Discussion}

Bupleurum rubrum subp. paniculatum essential oils from Portugal showed high amounts of monoterpene hydrocarbons with $\alpha$-pinene, $\beta$-pinene and limonene standing out as the main compounds. Similar compounds were also reported for essential oils obtained from plants collected in Montes Toledo, Spain, although in these plants myrcene was also found in high amounts (26.2\%) [36]. These differences might be due to different growing locations with diverse abiotic factors that may influence the biosynthesis of essential oils. In a previous work, we developed a protocol for the in vitro propagation of Bupleurum species and observed the presence of the major compounds inside secretory ducts of the in vitro propagated plantlets of $B$. rigidum subsp. paniculatum [37]. Since secondary metabolites signature in spontaneous plants was also found in the in vitro propagated plants, this technique could enable a large-scale production of this species, thus reducing the influence of abiotic factors and enabling the production of uniform essential oils. Furthermore, this approach could allow a year-round plant supply.

To the best knowledge of the authors, no reports on the bioactive potential of $B$. rigidum subsp. paniculatum have been conducted. Nevertheless, the antimicrobial activity of other Bupleurum species has already been reported. For example, the essential oil isolated from B. marginatum, rich in tridecane, undecane, pentadecane, $\beta$-caryophyllene and $\beta$-caryophyllene oxide, showed a MIC of $4 \mathrm{mg} / \mathrm{mL}$ towards two strains of $C$. albicans and inhibited several bacterial strains, including methicillin-resistant $S$. aureus (MIC $=0.063-4 \mathrm{mg} / \mathrm{mL}$ ) [22]. The antifungal activity of B. gibraltaricum, characterized by sabinene, $\alpha$-pinene and 2,3,4-trimethylbenzaldehyde, was demonstrated for Plasmopara halstedii through fungal sporulation inhibition at $5 \mathrm{~mL} / \mathrm{L}$ [30]. The essential oil from B. longiradiatum, having thymol, butylidene phthalide, 5-indolol, heptanal, 4-hydroxy-2methylacetophenone, 4,5-diethyl-octane, borneol and hexanoic acid as main compounds, was able to inhibit the growth of several bacteria with MIC ranging from 250-500 $\mu \mathrm{g} / \mathrm{mL}$ [27]. The essential oil herein presented showed a broad antifungal activity, very effective against Cryptococcus neoformans and Trichophyton rubrum (MIC $=72 \mu \mathrm{g} / \mathrm{mL}$ ). The antifungal effect of the essential oil might be attributed to the presence of several compounds with strong antifungal activity, namely $\alpha$-pinene, limonene, $\beta$-pinene and myrcene [38-46]. Regarding the anti-virulent effects of Bupleurum spp., no studies have been conducted until now. Nevertheless, the major compounds of the essential oil were able to decrease the yeast-to-hypha transition in C. albicans. Indeed, $\beta$-pinene $[47,48]$ and limonene [48] were described as germ tube inhibitors. Similarly, the capacity of the oil to disrupt preformed C. albicans biofilms might also be attributed to the presence of limonene and $\beta$-pinene as both compounds 
have been described as effective in disrupting mature biofilms. Nevertheless, the influence of minor compounds cannot be discarded. Indeed, myrcene and $p$-cymene were also able to inhibit the formation of C. albicans biofilms [48].

Regarding ultrastructural characterizations, studies on dermatophytes are scarce, thus highlighting the relevance of our results. In Candida species, essential oils tend to act on ergosterol synthesis, modify fungal cell morphology, modulate membrane permeability and produce reactive oxygen species [49]. In accordance, our observations showed alterations in the cell wall structure as well as cytoplasmic disorganization, thus contributing to an overall modification of fungal cell morphology. Similar effects were reported for conventional antifungal drugs, namely caspofungin alone or in conjugation with pyroquilon in Alternaria infectoria [50], suggesting a similar mechanism of action for B. rigidum subsp. paniculatum essential oils. Regarding T. rubrum, our results clearly show that the essential oil induces an increase in the number of vacuoles, thus suggesting an activation of autophagic pathways. Similar results were shown for Microsporum gypseum treated with resorcinol derivatives [35].

Furthermore, the present study reports for the first time the anti-inflammatory potential of B. rigidum subsp. paniculatum. Nevertheless, other studies have pointed out promising effects for other Bupleurum species. For example, the essential oil from B. fruticosum, rich in $\alpha$ - and $\beta$-pinene, thymol and carvacrol, was able to decrease the edema in a carrageenan-induced edema model [23] and that of $B$. frutiscens, characterized by $\alpha$-pinene and $\beta$-caryophyllene, also showed effects in paw edema induced by carrageenan and prostaglandin (PG) E1 [24]. Moreover, B. gibraltaricum essential oil with high amounts of $\Delta$-3-carene and $\alpha$-pinene, showed anti-inflammatory effects in both carrageenan-induced paw edema and granuloma-induced inflammation [51,52]. Additionally, the production of PGE2 and the activity of lipoxygenase was decreased in the presence of $B$. marginatum essential oil [22]. Overall, these results corroborate the anti-inflammatory effects observed in the present study as all species present similar major compounds to those found in $B$. rigidum subsp. paniculatum, namely pinene isomers. Accordingly, several reports have shown the anti-inflammatory effect of isolated major compounds including $\alpha$ - and $\beta$ pinene as well as limonene [53-55]. In addition, minor compounds, such as 1,8-cineole [56], camphor [56,57] and $\gamma$-terpinene [58] have also been assessed in a plethora of assays, thus suggesting that these compounds may contribute to B. rigidum subsp. paniculatum anti-inflammatory potential.

\section{Conclusions}

Overall, the present study provides evidence, for the first time, of the antifungal and anti-inflammatory potential of $B$. rigidum subsp. paniculatum essential oil from Portugal. The oil showed high amounts of monoterpene hydrocarbons (94.4-96.6\%), namely $\alpha$-pinene (29.0-36.0\%), $\beta$-pinene (26.1-30.7\%) and limonene (10.5-13.5\%) and demonstrated a broad fungicidal effect, particularly against Cryptococcus neoformans and Trichophyton rubrum. Moreover, a significant germ tube inhibition as well as a disruption of mature biofilms for C. albicans was pointed out and for both $C$. albicans and T. rubrum significant ultrastructural alterations were observed. Finally, B. rigidum subsp. paniculatum essential oil also evidenced anti-inflammatory activity, without affecting macrophages' viability, further endorsing its exploitation as a natural source of bioactive compounds for the development of drugs with concomitant antifungal and anti-inflammatory effects. Nevertheless, further in vivo studies are needed to validate the efficacy of the essential oil. Moreover, the clinical relevance of our results depends on the availability of the essential oil on target organs. Therefore, pharmacokinetic studies are essential to link in vitro effects to in vivo efficacy.

\section{Materials and Methods}

\subsection{Plant Material}

Aerial parts of two samples of B. rigidum subsp. paniculatum $(\sim 1 \mathrm{~kg})$ were collected from field-growing plants in the flowering stage in central Portugal [A-Coimbra region $\left(40^{\circ} 14^{\prime} 52.4^{\prime \prime} \mathrm{N} 8^{\circ} 25^{\prime} 14.1^{\prime \prime} \mathrm{W}\right)$, B-Fatima region $\left.\left(39^{\circ} 37^{\prime} 28.6^{\prime \prime} \mathrm{N} 8^{\circ} 41^{\prime} 19.7^{\prime \prime} \mathrm{W}\right)\right]$. Voucher 
specimens were deposited at the herbarium of the Department of Life Sciences of the University of Coimbra (COI).

\subsection{Essential Oil Isolation and Chemical Analysis}

The essential oils were obtained by hydrodistillation $(3 \mathrm{~h})$ using a Clevenger-type apparatus as described in the European Pharmacopoeia [59]. Their chemical characterization was carried out using both gas chromatography (GC) and gas chromatography coupled to mass spectrometry (GC-MS).

A Hewlett-Packard 6890 (Agilent Technologies, Palo Alto, CA, USA) chromatograph with a single injector, two flame ionization detectors and a HP GC ChemStation Rev. A.05.04 data handling system was used for GC analysis. Two columns: polydimethylsiloxane (SPB-1) and polyethylene glycol (SupelcoWax-10) with $30 \mathrm{~m} \times 0.20 \mathrm{~mm}$ and a film thickness $0.20 \mu \mathrm{m}$ were used and GC parameters were as follows: oven temperature: $70-220{ }^{\circ} \mathrm{C}$ $\left(3{ }^{\circ} \mathrm{C} / \mathrm{min}\right), 220^{\circ} \mathrm{C}(15 \mathrm{~min})$; injector temperature: $250{ }^{\circ} \mathrm{C}$; carrier gas: helium, with a linear velocity of $30 \mathrm{~cm} / \mathrm{s}$; splitting ratio 1:40; detectors temperature: $250^{\circ} \mathrm{C}$. A HewlettPackard 6890 gas chromatograph (SPB-1 column), interfaced with an Hewlett-Packard mass selective detector 5973 (Agilent Technologies, Centerville Road Wilmington, DE, USA) with a HP Enhanced ChemStation software, version A.03.00 (Agilent Technologies, Palo Alto, CA, USA) was used for GC-MS analysis. MS parameters: source temperature: $230^{\circ} \mathrm{C}$; MS quadruple temperature: $150^{\circ} \mathrm{C}$; ionization energy: $70 \mathrm{eV}$; ionization current: $60 \mu \mathrm{A}$; scan range: $35-350$ units; scans per second: 4.51 ; interface temperature: $250{ }^{\circ} \mathrm{C}$.

Retention indices and mass spectra were used to identify the compounds with the first being compared to samples from the Laboratory of Pharmacognosy database of the Faculty of Pharmacy, University of Coimbra and the later with that of reference spectra from a home-made library or from literature data. GC peak area was used to calculate relative amounts of the identified compounds.

\subsection{Antifungal Activity}

\subsubsection{Fungal Strains}

Collection and clinical strains were used to assess the antifungal effect of the essential oil, including yeasts: Candida albicans ATCC 10231, C. guillermondii MAT23, C. krusei H9, C. parapsilosis ATCC 90018, C. tropicalis ATCC 13803, and Cryptococcus neoformans CECT 1078; dermatophytes: Epidermophyton floccosum FF9, Microsporum canis FF1, M. gypseum CECT 2908, Trichophyton mentagrophytes FF7, T. mentagrophytes var. interdigitale CECT 2958, T. rubrum CECT 2794, and T. verrucosum CECT 2992 and Aspergillus strains including A. flavus F44, A. fumigatus ATCC 46645 and A. niger ATCC 16404.

The fungal isolates were identified by standard microbiological methods and stored at $-80{ }^{\circ} \mathrm{C}$ on Sabouraud broth with $20 \%$ glycerol, being inoculated on Sabouraud dextrose agar (SDA) to ensure optimal growth and purity, prior to each assay.

\subsubsection{Fungal Growth}

To assess the effect of the essential oil on fungal growth, two parameters were assessed: the minimal inhibitory concentration (MIC) and the minimal lethal concentration (MLC). A broth macrodilution method was used according to the Clinical and Laboratory Standards Institute (CLSI) reference protocols M27-A3 and M38-A2, for yeasts and filamentous fungi, respectively. Serial dilutions of the oil (up to $0.036 \mu \mathrm{g} / \mathrm{mL}$ ) were tested as well as a negative control (medium without fungi) and a positive control (inoculated medium with DMSO 1\%).

\subsubsection{Fungal Ultrastructure}

C. albicans and T. rubrum were selected to perform the transmission electron microscopy studies. Cultures untreated (DMSO 1\%) or treated with the essential oil (MIC) were used. Fungi cultures were collected and centrifuged at $3000 \mathrm{rpm}$ for $5 \mathrm{~min}$. Pellet cells were fixed using $2.5 \%$ glutaraldehyde in $0.1 \mathrm{M}$ sodium cacodylate buffer ( $\mathrm{pH} 7.2)$ for $2 \mathrm{~h}$ and 
post-fixed in $1 \%$ osmium tetroxide during $1 \mathrm{~h}$. Following rinsing, samples were embedded in $2 \%$ molten agar, dehydrated in ethanol (30-100\%), and impregnated and included in epoxy resin (Sigma Aldrich, St. Louis, MO, USA). Ultrathin sections $(70 \mathrm{~nm})$ were obtained and stained with uranyl acetate $2 \%$, for $5 \mathrm{~min}$ followed by lead citrate $0.2 \%$ for $5 \mathrm{~min}$. Observations were carried out on a FEI Tecnai G2 Spirit Bio Twin at $100 \mathrm{kV}$.

\subsubsection{Candida albicans Germ Tube Formation}

To assess the effect of the oil on the yeast-hyphae transition, cell suspensions of $C$. albicans ATCC 10231, from overnight cultures on SDA, were prepared in NYP medium [N-acetylglucosamine (10-3 mol/L), Yeast Nitrogen Base (3.35 g/L), proline (10-3 mol/L), $\mathrm{NaCl}(4.5 \mathrm{~g} / \mathrm{L})$, and $\mathrm{pH} 6.7 \pm 0.1$ [ [60]. The suspensions were adjusted to a density of $1.0 \pm 0.2 \times 10^{6} \mathrm{CFU} / \mathrm{mL}$ and then distributed into glass test tubes $(990 \mu \mathrm{L})$. Then, subinhibitory concentrations of the essential oil or fluconazole $(10 \mu \mathrm{L})$ were added and incubated without agitation for $3 \mathrm{~h}$, at $37^{\circ} \mathrm{C}$. The number of germ tubes (germinating protuberance at least as long as the diameter of the blastopore) were recorded using a light microscope $(40 \times)$ and DMSO $1 \%(v / v)$ was used as a positive control.

\subsubsection{Candida albicans Biofilm Disruption}

Serial dilutions of the essential oil (1125-72 $\mu \mathrm{g} / \mathrm{mL})$ and fluconazole $(200-1 \mu \mathrm{g} / \mathrm{mL})$ were used to assess their effect on mature biofilms, as reported elsewhere [61]. C. albicans density was adjusted to $1 \times 10^{6} \mathrm{CFU} / \mathrm{mL}$ and $100 \mu \mathrm{L}$ of this suspension added to 96 -well microtiter plates and incubated for $24 \mathrm{~h}$ at $37^{\circ} \mathrm{C}$ for biofilm adhesion and formation, followed by $24 \mathrm{~h}$ at $37^{\circ} \mathrm{C}$ in the presence or absence of the essential oils.

Biofilm viability was determined using the $\mathrm{XTT} /$ menadione metabolic assay. Briefly, menadione (10 $\mathrm{mM}$ in acetone) was added to a XTT solution $(1 \mathrm{mg} / \mathrm{mL}$ in PBS) to a final concentration of $4 \mu \mathrm{M}$. A volume of $100 \mu \mathrm{L}$ of this solution was added to each well and incubated for $2 \mathrm{~h}$ at $37^{\circ} \mathrm{C}$ in the dark. The absorbance was measured at $490 \mathrm{~nm}$ and cell viability expressed as [(AbsT/AbsC) $\times 100]$, where AbsT represents the absorbance of the treated cells and $\mathrm{AbsC}$ the absorbance of control cells (without essential oil or fluconazole).

Biofilm biomass was assessed using the crystal violet assay. Following the treatment period, performed as referred above, the culture medium was removed and cells were fixed with methanol $99 \%$ for $15 \mathrm{~min}$. The supernatant was discarded, and the wells air dried. Then, $100 \mu \mathrm{L}$ of crystal violet (CV) solution $(0.02 \%)$ was added to each well and left to stain the biofilm for $15 \mathrm{~min}$. After CV removal, the wells were washed twice with sterile water to remove excessive reagent. Then, $150 \mu \mathrm{L}$ of acetic acid $33 \%$ were added to release the stain from the cells and the supernatant was transferred to a 96-well microtiter plate. The absorbance was then read at $620 \mathrm{~nm}$ using a microtiter plate reader. Biomass decrease was determined as [(AbsT/AbsC) $\times 100]$, where AbsT represents the absorbance of each treated well and $\mathrm{AbsC}$ the absorbance in the control wells. Negative and positive controls comprising biofilm-free and oil-free wells, respectively, were also included.

\subsection{Anti-Inflammatory Activity \\ 5.4.1. Cell Culture}

The mouse macrophage cell line, Raw 264.7 (ATCC number: TIB-71) was kindly supplied by Dr. Otilia Vieira (CEDOC, Faculdade de Ciências Médicas, Universidade Nova de Lisboa). The cells were cultured on endotoxin-free Dulbecco's Modified Eagle Medium (DMEM) supplemented with 10\% $(v / v)$ non-inactivated fetal bovine serum, $3.02 \mathrm{~g} / \mathrm{L}$ sodium bicarbonate, $100 \mathrm{\mu g} / \mathrm{mL}$ streptomycin and $100 \mathrm{U} / \mathrm{mL}$ penicillin at $37^{\circ} \mathrm{C}$ in a humidified atmosphere with $5 \% \mathrm{CO}_{2}$. Morphological appearance of macrophages was microscopically monitored during the assays.

\subsubsection{Assessment of Nitric Oxide (NO) Production}

To evaluate the anti-inflammatory potential of the oils, the in vitro model of lipopolysaccharide (LPS)-stimulated macrophages was used. The cells $\left(0.6 \times 10^{6}\right.$ cells/well) were 
cultured in a 48-well microplate and left to stabilize for $12 \mathrm{~h}$. The cells were then incubated for $24 \mathrm{~h}$ in the culture medium alone (control) or with different concentrations of the essential oils (144-576 $\mu \mathrm{g} / \mathrm{mL})$. The production of nitric oxide (NO) was measured by the accumulation of nitrites in the culture medium, using the colorimetric Griess reaction. Briefly, $170 \mu \mathrm{L}$ of culture supernatants were added to an equal volume of Griess reagent [0.1\% $(w / v) \mathrm{N}-(1-$ naphthyl)-ethylenediamine dihydrochloride and $1 \%(w / v)$ sulphanilamide containing $\left.5 \%(w / v) \mathrm{H}_{3} \mathrm{PO}_{4}\right]$ and maintained for $30 \mathrm{~min}$, in the dark. Absorbance was measured using an ELISA automatic microplate reader (SLT, Austria) at $550 \mathrm{~nm}$ and the nitrite concentration determined from a regression analysis prepared with serial dilutions of sodium nitrite.

\subsubsection{Assessment of Cell Viability}

Cell respiration, an indicator of cell viability, was performed using a colorimetric assay with 3-(4,5-dimethylthiazol-2-yl)-2,5-diphenyl tetrazolium bromide (MTT). The cells were cultured and treated as referred above. After cells treatments, $43 \mu \mathrm{L}$ of MTT solution ( $5 \mathrm{mg} / \mathrm{mL}$ in phosphate buffered saline) were added to each well and the microplates were further incubated at $37^{\circ} \mathrm{C}$ for $15 \mathrm{~min}$, in a humidified atmosphere with $5 \% \mathrm{CO}_{2}$. Supernatants were centrifuged $(1000 \times g$ during $5 \mathrm{~min})$ to recover viable cells. To dissolve formazan crystals formed in adherent cells in the microplates, $300 \mu \mathrm{L}$ of acidified isopropanol $(0.04 \mathrm{M} \mathrm{HCl}$ in isopropanol) were added to each cell and recovered to the respective tube containing the pellet formed after centrifugation. Quantification of formazan was performed using an ELISA automatic microplate reader (SLT, Salzburg, Austria) at $570 \mathrm{~nm}$.

\subsection{Statistical Analysis}

The results presented as mean $\pm \mathrm{SD}$ are from experiments performed at least in triplicate. The statistical test one-way ANOVA followed by Dunnett's Multiple Comparison Test were performed using GraphPad Prism, version 6 (GraphPad Software, San Diego, CA, USA).

Author Contributions: Conceptualization, M.Z. and L.S.; methodology, M.Z., P.M.P.C., J.M.A.-S., M.J.G., C.C.; validation, P.M.P.C., J.M.A.-S.; formal analysis, M.Z., J.M.A.-S.; investigation, M.Z., M.J.G., P.M.P.C.; resources, C.C., T.C., L.S.; writing—original draft preparation, M.Z.; writingP.M.P.C., J.M.A.-S., C.C., M.J.G., T.C., L.S.; visualization, M.Z., J.M.A.-S.; supervision, L.S.; funding acquisition, T.C., L.S. All authors have read and agreed to the published version of the manuscript.

Funding: This work was financed by the European Regional Development Fund (ERDF), through the Centro 2020 Regional Operational Programme under project CENTRO-01-0145-FEDER-000012 (HealthyAging2020).

Data Availability Statement: Data is contained within the article.

Acknowledgments: Electron microscopy analysis were carried out at the Microscopy and Bioimaging Lab of the Faculty of Medicine of the University of Coimbra, supported by the Portuguese Platform of Bioimaging, PPBI-POCI-01-0145-FEDER-02212.

Conflicts of Interest: The authors declare no conflict of interest.

\section{References}

1. Bongomin, F.; Gago, S.; Oladele, R.; Denning, D. Global and multi-national prevalence of fungal diseases-Estimate precision. J. Fungi 2017, 3, 57. [CrossRef]

2. Pierce, C.; Lopez-Ribot, J.L. Candidiasis drug discovery and development: New approaches targeting virulence for discovering and identifying new drugs. Expert Opin. Drug Discov. 2013, 8, 1117-1126. [CrossRef] [PubMed]

3. Makanjuola, O.; Bongomin, F.; Fayemiwo, S. An Update on the roles of non-albicans Candida species in vulvovaginitis. J. Fungi 2018, 4, 121. [CrossRef] [PubMed]

4. Dadar, M.; Tiwari, R.; Karthik, K.; Chakraborty, S.; Shahali, Y.; Dhama, K. Candida albicans_Biology, molecular characterization, pathogenicity, and advances in diagnosis and control-An update. Microb. Pathog. 2018, 117, 128-138. [CrossRef] 
5. Romo, J.A.; Pierce, C.G.; Chaturvedi, A.K.; Lazzell, A.L.; McHardy, S.F.; Saville, S.P.; Lopez-Ribot, J.L. Development of antivirulence approaches for candidiasis via a novel series of small-molecule inhibitors of Candida albicans filamentation. $m$ Bio 2017,8 . [CrossRef]

6. Silva, S.; Rodrigues, C.; Araújo, D.; Rodrigues, M.; Henriques, M. Candida species biofilms' antifungal resistance. J. Fungi 2017, 3, 8. [CrossRef]

7. Lee, J.-H.; Kim, Y.-G.; Gupta, V.K.; Manoharan, R.K.; Lee, J. Suppression of fluconazole resistant Candida albicans biofilm formation and filamentation by methylindole derivatives. Front. Microbiol. 2018, 9. [CrossRef]

8. Sugui, J.A.; Kwon-Chung, K.J.; Juvvadi, P.R.; Latge, J.-P.; Steinbach, W.J. Aspergillus fumigatus and related species. Cold Spring Harb. Perspect. Med. 2015, 5, a019786. [CrossRef]

9. Fuentefria, A.M.; Pippi, B.; Dalla Lana, D.F.; Donato, K.K.; de Andrade, S.F. Antifungals discovery: An insight into new strategies to combat antifungal resistance. Lett. Appl. Microbiol. 2018, 66, 2-13. [CrossRef] [PubMed]

10. Martinez-Rossi, N.M.; Bitencourt, T.A.; Peres, N.T.A.; Lang, E.A.S.; Gomes, E.V.; Quaresemin, N.R.; Martins, M.P.; Lopes, L.; Rossi, A. Dermatophyte resistance to antifungal drugs: Mechanisms and prospectus. Front. Microbiol. 2018, 9. [CrossRef]

11. Colombo, A.L.; de Almeida Júnior, J.N.; Guinea, J. Emerging multidrug-resistant Candida species. Curr. Opin. Infect. Dis. 2017, 30, 528-538. [CrossRef] [PubMed]

12. Taghavi, M.; Khosravi, A.; Mortaz, E.; Nikaein, D.; Athari, S.S. Role of pathogen-associated molecular patterns (PAMPS) in immune responses to fungal infections. Eur. J. Pharm. 2017, 808, 8-13. [CrossRef]

13. Chen, L.; Deng, H.; Cui, H.; Fang, J.; Zuo, Z.; Deng, J.; Li, Y.; Wang, X.; Zhao, L. Inflammatory responses and inflammationassociated diseases in organs. Oncotarget 2018, 9, 7204-7218. [CrossRef] [PubMed]

14. Vega, R.J.S.; Xolalpa, N.C.; Castro, A.J.A.; González, C.P.; Ramos, J.P.; Gutiérrez, S.P. Terpenes from natural products with potential anti-inflammatory activity. In Terpenes and Terpenoids; IntechOpen: London, UK, 2018; pp. 59-85.

15. Sun, S.-C. The non-canonical NF-кB pathway in immunity and inflammation. Nat. Rev. Immunol. 2017, 17, 545-558. [CrossRef]

16. Kumamoto, C.A. Inflammation and gastrointestinal Candida colonization. Curr. Opin. Microbiol. 2011, 14, 386-391. [CrossRef] [PubMed]

17. Bindu, S.; Mazumder, S.; Bandyopadhyay, U. Non-steroidal anti-inflammatory drugs (NSAIDs) and organ damage: A current perspective. Biochem. Pharm. 2020, 180, 114147. [CrossRef] [PubMed]

18. Alves-Silva, J.M.; Zuzarte, M.; Gonçalves, M.J.; Cavaleiro, C.; Cruz, M.T.; Cardoso, S.M.; Salgueiro, L. New claims for wild carrot (Daucus carota subsp. carota) essential oil. Evid. Based Complement. Altern. Med. 2016, 2016, 1-10. [CrossRef]

19. Valente, J.; Zuzarte, M.; Resende, R.; Gonçalves, M.J.; Cavaleiro, C.; Pereira, C.F.; Cruz, M.T.; Salgueiro, L. Daucus carota subsp gummifer essential oil as a natural source of antifungal and anti-inflammatory drugs. Ind. Crop. Prod. 2015, 65, 361-366. [CrossRef]

20. Yao, R.; Zou, Y.; Chen, X. Traditional use, pharmacology, toxicology, and quality control of species in genus Bupleurum L. Chin. Herb. Med. 2013, 5, 245-255. [CrossRef]

21. Prieto, J.M.; Ogunsina, M.O.; Novak, A.; Joshi, A.; Kokai, J.; Rocha, I.D.C.; de Santayana, M.P. Comparative study of the in vitro bioactivities of Bupleurum rigidum and B. fruticescens. Nat. Prod. Commun. 2012, 7. [CrossRef]

22. Ashour, M.L.; El-Readi, M.; Youns, M.; Mulyaningsih, S.; Sporer, F.; Efferth, T.; Wink, M. Chemical composition and biological activity of the essential oil obtained from Bupleurum marginatum (Apiaceae). J. Pharm. Pharm. 2009, 61, 1079-1087. [CrossRef]

23. Lorente, I.; Ocete, M.A.; Zarzuelo, A.; Cabo, M.M.; Jimenez, J. Bioactivity of the essential oil of Bupleurum fruticosum. J. Nat. Prod. 1989, 52, 267-272. [CrossRef]

24. Martin, S.; Padilla, E.; Ocete, M.; Galvez, J.; Jiménez, J.; Zarzuelo, A. Anti-inflammatory activity of the essential oil of Bupleurum Fruticescens. Planta Med. 1993, 59, 533-536. [CrossRef]

25. Guinea, M.; Parellada, J.; Lacaille-Dubois, M.; Wagner, H. Biologically active triterpene saponins from Bupleurum fruticosum. Planta Med. 1994, 60, 163-167. [CrossRef]

26. Yen, M.-H.; Weng, T.-C.; Liu, S.-Y.; Chai, C.-Y.; Lin, C.-C. The hepatoprotective effect of Bupleurum kaoi, an endemic plant to Taiwan, against dimethylnitrosamine-induced hepatic fibrosis in rats. Biol. Pharm. Bull. 2005, 28, 442-448. [CrossRef]

27. Shi, B.; Liu, W.; Wei, S.-P.; Wu, W.-J. Chemical composition, antibacterial and antioxidant activity of the essential oil of Bupleurum longiradiatum. Nat. Prod. Commun. 2010, 5, 1139-1142. [CrossRef] [PubMed]

28. Shafaghat, A. Antioxidant, antimicrobial activities and fatty acid components of leaf and seed of Bupleurum lancifolium hornem. J. Med. Plants Res. 2011, 5, 3758-3762.

29. Maxia, A.; Frau, M.A.; Marongiu, B.; Piras, A.; Porcedda, S.; Falconieri, D.; Gonçalves, M.J.; Cavaleiro, C.; Salgueiro, L. Biological assays and chemical composition of volatile oils of Bupleurum fruticosum L. (Apiaceae). Rec. Nat. Prod. 2011, 5, 92-99.

30. Fernández-Ocaña, A.M.; Gómez-Rodríguez, M.V.; Velasco-Negueruela, A.; Camacho-Simarro, A.M.; Fernández-López, C.; Altarejos, J. In vivo antifungal activity of the essential oil of Bupleurum gibraltarium against Plasmopara halstedii in sunflower. J. Agric. Food Chem. 2004, 52, 6414-6417. [CrossRef]

31. Lartaud, P.; Pegeon, A.; Pelletier, P. Cosmetic Use of Essential Oil of Bupleurum fruticosum 2011; WO/2012/080992; L'OREAL: Clichy, France, 2012.

32. Contreras, S.S.; Lanza, A.M.D.; Pajares, M.B.; Esteban, C.B.; Castillo, L.V.; Martínez, M.J.A.; Benito, P.B.; Matellano, L.F. Bioactive components of Bupleurum rigidum L. subsp. rigidum. In Studies in Natural Products Chemistry; Elsevier: Amsterdam, The Netherlands, 2002; pp. 659-696. 
33. Mukaremera, L.; Lee, K.K.; Mora-Montes, H.M.; Gow, N.A.R. Candida albicans yeast, pseudohyphal, and hyphal morphogenesis differentially affects immune recognition. Front. Immunol. 2017, 8, 629. [CrossRef] [PubMed]

34. Cardoso, N.N.R.; Alviano, C.S.; Blank, A.F.; Romanos, M.T.V.; Fonseca, B.B.; Rozental, S.; Rodrigues, I.A.; Alviano, D.S. Synergism effect of the essential oil from Ocimum basilicum var. Maria Bonita and its major components with fluconazole and its influence on ergosterol biosynthesis. Evid. Based Complement. Altern. Med. 2016, 2016, 1-12. [CrossRef] [PubMed]

35. Romagnoli, C.; Baldisserotto, A.; Vicentini, C.; Mares, D.; Andreotti, E.; Vertuani, S.; Manfredini, S. Antidermatophytic action of resorcinol derivatives: Ultrastructural evidence of the activity of phenylethyl resorcinol against Microsporum Gypseum. Molecule 2016, 21, 1306. [CrossRef] [PubMed]

36. Palá-Paúl, J.; Pérez-Alonso, M.J.; Velasco-Negueruela, A. Volatile constituents isolated from the essential oil of Bupleurum rigidum ssp. paniculatum (Brot.) H. Wolff. J. Essent. Oil Res. 1999, 11, 456-458. [CrossRef]

37. Correia, P.; Canhoto, J.M.; Zuzarte, M.; Salgueiro, L. Bupleurum spp. in central Portugal: In vitro propagation and secretory ducts. Acta Hortic. 2015, 1083, 527-534. [CrossRef]

38. Yousefzadi, M.; Sonboli, A.; Ebrahimi, S.N.; Hashemi, S.H. Antimicrobial activity of essential oil and major constituents of Salvia chloroleuca. Z. Nat. C 2008, 63, 337-340. [CrossRef] [PubMed]

39. Tampieri, M.P.; Galuppi, R.; Macchioni, F.; Carelle, M.S.; Falcioni, L.; Cioni, P.L.; Morelli, I. The inhibition of Candida albicans by selected essential oils and their major components. Mycopathologia 2005, 159, 339-345. [CrossRef]

40. Sonboli, A.; Babakhani, B.; Mehrabian, A.R. Antimicrobial activity of six constituents of essential oil from Salvia. Z. Nat. C. 2006, $61,160-164$.

41. Rajput, S.B.; Karuppayil, S.M. Small molecules inhibit growth, viability and ergosterol biosynthesis in Candida albicans. Springerplus 2013, 2, 26. [CrossRef]

42. Pinto, E.; Hrimpeng, K.; Lopes, G.; Vaz, S.; Gonçalves, M.J.; Cavaleiro, C.; Salgueiro, L. Antifungal activity of Ferulago capillaris essential oil against Candida, Cryptococcus, Aspergillus and dermatophyte species. Eur. J. Clin. Microbiol. Infect. Dis. 2013, 32, 1311-1320. [CrossRef] [PubMed]

43. Sekine, T.; Sugano, M.; Majid, A.; Fujii, Y. Antifungal effects of volatile compounds from black zira (Bunium persicum) and other spices and herbs. J. Chem. Ecol. 2007, 33, 2123-2132. [CrossRef]

44. Leite, A.M.; de Oliveira Lima, E.; de Souza, E.L.; de Fátima Formiga Melo Diniz, M.; Trajano, V.N.; de Medeiros, I.A. Inhibitory effect of beta-pinene, alpha-pinene and eugenol on the growth of potential infectious endocarditis causing Gram-positive bacteria. Rev. Bras. Ciências Farm. 2007, 43, 121-126. [CrossRef]

45. Hammer, K.A.; Carson, C.F.; Riley, T.V. Antifungal activity of the components of Melaleuca alternifolia (tea tree) oil. J. Appl. Microbiol. 2003, 95, 853-860. [CrossRef] [PubMed]

46. Filipowicz, N.; Kamiński, M.; Kurlenda, J.; Asztemborska, M.; Ochocka, J.R. Antibacterial and antifungal activity of juniper berry oil and its selected components. Phyther. Res. 2003, 17, 227-231. [CrossRef] [PubMed]

47. Halbandge, S.D.; Mortale, S.P.; Jadhav, A.K. Differential Sensitivities of various growth modes of Candida albicans to sixteen molecules of plant origin. J. Pharm. Phytochem. 2017, 6, 306-318.

48. Raut, J.S.; Shinde, R.B.; Chauhan, N.M.; Mohan Karuppayil, S. Terpenoids of plant origin inhibit morphogenesis, adhesion, and biofilm formation by Candida albicans. Biofouling 2013, 29, 87-96. [CrossRef] [PubMed]

49. Serra, E.; Hidalgo-Bastida, L.; Verran, J.; Williams, D.; Malic, S. Antifungal activity of commercial essential oils and biocides against Candida albicans. Pathogens 2018, 7, 15. [CrossRef]

50. Fernandes, C.; Prados-Rosales, R.; Silva, B.M.A.; Nakouzi-Naranjo, A.; Zuzarte, M.; Chatterjee, S.; Stark, R.E.; Casadevall, A.; Gonçalves, T. Activation of melanin synthesis in Alternaria infectoria by antifungal drugs. Antimicrob. Agents Chemother. 2016, 60, 1646-1655. [CrossRef] [PubMed]

51. Gil, M.L.; Jimenez, J.; Ocete, M.A.; Zarzuelo, A.; Cabo, M.M. Comparative study of different essential oils of Bupleurum gibraltaricum Lamarck. Pharmazie 1989, 44, 284-287.

52. Ocete, M.A.; Risco, S.; Zarzuelo, A.; Jimenez, J. Pharmacological activity of the essential oil of Bupleurum gibraltaricum: Antiinflammatory activity and effects on isolated rat uteri. J. Ethnopharmacol. 1989, 25, 305-313. [CrossRef]

53. Coté, H.; Boucher, M.-A.; Pichette, A.; Legault, J. Anti-inflammatory, antioxidant, antibiotic, and cytotoxic activities of Tanacetum vulgare L. essential oil and its constituents. Medicines 2017, 4, 34. [CrossRef]

54. Rufino, A.T.; Ribeiro, M.; Sousa, C.; Judas, F.; Salgueiro, L.; Cavaleiro, C.; Mendes, A.F. Evaluation of the anti-inflammatory, anti-catabolic and pro-anabolic effects of E-caryophyllene, myrcene and limonene in a cell model of osteoarthritis. Eur. J. Pharm. 2015, 750, 141-150. [CrossRef] [PubMed]

55. Rufino, A.T.; Ribeiro, M.; Judas, F.; Salgueiro, L.; Lopes, M.C.; Cavaleiro, C.; Mendes, A.F. Anti-inflammatory and chondroprotective activity of (+)- $\alpha$-pinene: Structural and enantiomeric selectivity. J. Nat. Prod. 2014, 77, 264-269. [CrossRef]

56. Ehrnhöfer-Ressler, M.M.; Fricke, K.; Pignitter, M.; Walker, J.M.; Walker, J.; Rychlik, M.; Somoza, V. Identification of 1,8-cineole, borneol, camphor, and thujone as anti-inflammatory compounds in a Salvia officinalis L. infusion using human gingival fibroblasts. J. Agric. Food Chem. 2013, 61, 3451-3459. [CrossRef] [PubMed]

57. de Lima, V.T.; Vieira, M.C.; Kassuya, C.A.L.; Cardoso, C.A.L.; Alves, J.M.; Foglio, M.A.; de Carvalho, J.E.; Formagio, A.S.N. Chemical composition and free radical-scavenging, anticancer and anti-inflammatory activities of the essential oil from Ocimum kilimandscharicum. Phytomedicine 2014, 21, 1298-1302. [CrossRef] 
58. Ramalho, T.; Pacheco de Oliveira, M.; Lima, A.; Bezerra-Santos, C.; Piuvezam, M. Gamma-terpinene modulates acute inflammatory response in mice. Planta Med. 2015, 81, 1248-1254. [CrossRef] [PubMed]

59. Council of Europe. European Pharmacopoeia, 9th ed.; Council of Europe: Strasbourg, France, 2016.

60. Marichal, P.; Gorrens, J.; Cutsem, J.; Bossche, H. Vanden Culture media for the study of the effects of azole derivatives on germ tube formation and hyphal growth of C. albicans/Nährböden zur Untersuchung der Wirkungen von Azolderivaten auf die Keimschlauchbildung und das Hyphenwachstum bei C. albicans. Mycoses 2009, 29, 76-81. [CrossRef]

61. Alves, M.; Gonçalves, M.J.; Zuzarte, M.; Alves-Silva, J.M.; Cavaleiro, C.; Cruz, M.T.; Salgueiro, L. Unveiling the antifungal potential of two Iberian thyme essential oils: Effect on C. albicans germ tube and preformed biofilms. Front. Pharm. 2019, 10. [CrossRef] 